\title{
A New Acycloguanosine-Specific Supermutant of Herpes Simplex Virus Type 1 Thymidine Kinase Suitable for PET Imaging and Suicide Gene Therapy for Potential Use in Patients Treated with Pyrimidine-Based Cytotoxic Drugs
}

\author{
Yury Likar ${ }^{1}$, Konstantin Dobrenkov $^{1}$, Malgorzata Olszewska ${ }^{1}$, Elena Vider ${ }^{1}$, Larissa Shenker ${ }^{1}$, Shangde Cai ${ }^{2}$, \\ Nagavarakishore Pillarsetty ${ }^{1}$, Hedvig Hricak ${ }^{1}$, and Vladimir Ponomarev ${ }^{1}$ \\ ${ }^{1}$ Department of Radiology, Memorial Sloan-Kettering Cancer Center, New York, New York; and ${ }^{2}$ Radiochemistry/Cyclotron Core \\ Facility, Memorial Sloan-Kettering Cancer Center, New York, New York
}

\begin{abstract}
The herpes simplex virus type 1 thymidine kinase (HSV1-tk) gene is widely used as a suicide gene in combination with ganciclovir (GCV) and as a nuclear imaging reporter gene with an appropriate reporter probe. Wild-type HSV1-tk recognizes a variety of pyrimidine and acycloguanosine nucleoside analogs, including clinically used antiviral drugs. PET of HSV1-tk reporter gene expression will be compromised in patients receiving nucleoside-based antiviral treatment. With the use of an acycloguanosine-specific mutant of the enzyme, PET of HSV1-tk reporter gene expression can be successfully performed with acycloguanosine-based radiotracers without interference from pyrimidine-based antiviral drugs. Methods: The levels of expression of wild-type HSV1-tk and HSV1-A167Ytk, HSV1-sr39tk, and HSV1-A167Ysr39tk mutants fused with green fluorescent protein (GFP) and transduced into U87 cells were normalized to the mean fluorescence of GFP measured by fluorescence-activated cell sorting. The levels of enzymatic activities of wild-type HSV1-tk and its mutants were compared by 2 -h in vitro radiotracer uptake assays with ${ }^{3} \mathrm{H}-2^{\prime}$-fluoro-2'-deoxy-1- $\beta$-D-arabinofuranosyl-5ethyluracil ( $\left.{ }^{3} \mathrm{H}-\mathrm{FEAU}\right),{ }^{3} \mathrm{H}$-pencyclovir $\left({ }^{3} \mathrm{H}-\mathrm{PCV}\right)$, and ${ }^{3} \mathrm{H}-\mathrm{GCV}$ and by drug sensitivity assays. PET with ${ }^{18} \mathrm{~F}-\mathrm{FEAU}$ and ${ }^{18} \mathrm{~F}-9$ [4-fluoro-3-(hydroxymethyl)butyl]guanine ( $\left.{ }^{18} \mathrm{~F}-\mathrm{FHBG}\right)$ was performed in mice with established subcutaneous tumors, expressing wild-type HSV1-tk and its mutants, followed by tissue sampling. Results: FEAU accumulation was not detected in HSV1A167Ysr39tk-expressing cells and xenografts. Lack of conversion of pyrimidine derivatives by the HSV1-A167Ysr39tk supermutant was also confirmed by a drug sensitivity assay, in which the $50 \%$ inhibitory concentrations for thymine $1-\beta-D$-arabinofuranoside and bromovinyldeoxyuridine were found to be similar to those in nontransduced cells. In contrast, we found that HSV1A167Ysr39tk could readily phosphorylate ${ }^{3} \mathrm{H}-\mathrm{GCV}$ at levels similar to those of wild-type HSV1-tk and HSV1-A167Ytk but
\end{abstract}

Received Aug. 17, 2007; revision accepted Jan. 8, 2008.

For correspondence or reprints contact: Vladimir Ponomarev, Molecular Imaging Laboratory, Department of Radiology, Memorial Sloan-Kettering Cancer Center, 1275 York Ave., Box 50, Z-2063, New York, NY 10021.

E-mail: ponomarv@mskcc.org

COPYRIGHT $\odot 2008$ by the Society of Nuclear Medicine, Inc. showed enhanced activity with ${ }^{3} \mathrm{H}-\mathrm{PCV}$ in vitro and with ${ }^{18} \mathrm{~F}-$ FHBG in vivo. Conclusion: We developed a new reporter gene, HSV1-A167Ysr39tk, which exhibits specificity and high phosphorylation activity for acycloguanosine derivatives. The resulting supermutant can be used for PET with ${ }^{18} \mathrm{~F}-\mathrm{FHBG}$ and suicidal gene therapy protocols with GCV in patients treated with pyrimidine-based cytotoxic drugs.

Key Words: molecular imaging; reporter gene; HSV1-tk; PET; FEAU; ${ }^{18} \mathrm{~F}-\mathrm{FHBG}$

J Nucl Med 2008; 49:713-720

DOI: 10.2967/jnumed.107.046425

$\mathbf{N}$ in vivo is a rapidly expanding field in molecular imaging (1). The translation of reporter gene imaging technology to clinical applications is emerging from preclinical studies on the treatment of cancer (2) and infectious diseases (3) and cellular therapies $(4,5)$. Several reporter genes of different origins have been successfully tested in animal models as potential markers for clinical use; these include the herpes simplex virus type 1 thymidine kinase (HSV1-tk) $(6,7)$, human mitochondrial thymidine kinase type $2(8)$, human sodium iodide symporter (9), human norepinephrine transporter (10), human ferritin (11), and human transferrin receptor (12) genes.

HSV1-tk has been shown to be a nontoxic protein in humans and is currently being used in clinical gene therapy protocols as a prodrug activation enzyme in combination with ganciclovir (GCV) for cancer treatment (2) and for the control of graft-versus-host alloreactivity after bone marrow and stem cell transplantation (13). The wild-type HSV1-tk gene is also being widely used as a reporter gene for nuclear imaging with $2^{\prime}$-deoxy-2'-fluoro-5-iodo-1- $\beta$-D-arabinofuranosyluracil (FIAU) labeled with ${ }^{131} \mathrm{I}$ (6), ${ }^{123} \mathrm{I}$ (14), ${ }^{124} \mathrm{I}$ (15), ${ }^{125} \mathrm{I}$ (16), and 
${ }^{18} \mathrm{~F}$ (17) and its derivatives $2^{\prime}$-fluoro- $2^{\prime}$-deoxy-1- $\beta$-D-arabinofuranosyl-5-ethyluracil (FEAU) $(18,19), 2^{\prime}$-deoxy-2' fluoro-5-methyl-1- $\beta$-D-arabinofuranosyluracil (FMAU) (20), and 2 '-fluoro-2'-deoxy-5-fluoroethyl-1- $\beta$-D-arabinofuranosyluracil (FFEAU) (21) labeled with ${ }^{18} \mathrm{~F}$. A mutant of HSV1-tk, HSV1-sr39tk, with enhanced phosphorylation of acycloguanosine analogs has been successfully used for PET with an ${ }^{18} \mathrm{~F}$-labeled form of pencyclovir (PCV), ${ }^{18} \mathrm{~F}-9-[4-$ fluoro-3-(hydroxymethyl)butyl]guanine ( $\left.{ }^{18} \mathrm{~F}-\mathrm{FHBG}\right)$ (22). Initial clinical reporter gene imaging studies described by Jacobs et al. in 2001 demonstrated, for the first time, the successful visualization of liposome-mediated direct intratumoral HSV1-tk gene delivery and expression in human patients with glioblastomas by using ${ }^{124}$ I-FIAU and PET (23). Recently, Peñuelas et al. showed the feasibility of repetitive $\mathrm{PET}$ with ${ }^{18} \mathrm{~F}-\mathrm{FHBG}$ for monitoring reporter gene expression after intratumoral injection of an HSV1-tkexpressing adenovirus in patients with hepatocellular carcinomas followed by treatment with GCV (24).

HSV1-tk can phosphorylate several nucleoside analogs, including drugs clinically used for the treatment of viral diseases. Among them are the acycloguanosine derivatives GCV (Cytovene; Roche) (25) and acyclovir (ACV; Zovirax; GlaxoSmithKline) (26) and pyrimidine-based bromovinyldeoxyuridine (BVdU; Brivudin; ZOSTEX) (27). However, the administration of these drugs in patients undergoing gene therapy with HSV1-tk will be detrimental to the transduced cells and will lead to negative imaging results with HSV1-tkspecific PET tracers. This shortcoming can be potentially overcome by use of a pyrimidine- or acycloguanosinerestricted variant of the HSV1-tk enzyme for PET, which will allow the use of an alternative class of drugs for the control of viral infections.

In this study, we tested in vitro and in vivo a recently described HSV1-tk mutant bearing an alanine-to-tyrosine substitution at position 167 (A167Y) $(28,29)$ and showing a significantly reduced ability to phosphorylate pyrimidinebased nucleoside analogs, including clinically administered medications and radiotracers. On the basis of these data and given the potential use of the HSV1-tk reporter gene in patients treated with pyrimidine-based cytotoxic drugs, we developed and tested a new HSV1-tk supermutant, HSV1A167Ysr39tk, which lacks the ability to phosphorylate pyrimidine-based nucleoside derivatives but exhibits high phosphorylation activity with acycloguanosine analogs, including GCV for suicidal function and ${ }^{18} \mathrm{~F}-\mathrm{FHBG}$ for clinical PET.

\section{MATERIALS AND METHODS}

\section{Retroviral Vectors}

The schematic structures of the retroviral vectors used in this study are shown in Figure 1. A retroviral vector containing a wildtype HSV1-tk/green fluorescent protein (GFP) fusion reporter gene with a nuclear export signal (NES) from mitogen-activated protein kinase kinase of Xenopus (SFG-Nes-wild-type HSV1-tk/ GFP) was described previously (30) and served as a reference vector (wild-type HSV1-tk). The HSV1-sr39tk mutant (kindly provided by S.S. Gambhir, University of Stanford, Stanford, CA) (Fig. 1A) was introduced into the SFG-Nes-wild-type HSV1-tk/ GFP vector and replaced wild-type HSV1-tk, resulting in the SFG-Nes-HSV1-sr39tk/GFP retroviral vector (HSV1-sr39tk). An alanine-to-tyrosine substitution at position 167 in the wild-type HSV1-tk and HSV1-sr39tk genes was performed with the primer pairs 5'-CATCCCATCTACGCCCTCCTG-3' and 5' -CAGGAGGGCGTAGATGGGATG-3' for the SFG-Nes-wild-type HSV-tk/ GFP vector and 5'-CATCCCATCTACTTCATGCTGTGCTAC-3' and $5^{\prime}$-CATGAAGTAGATGGGATGGCGGTCGAG-3' for the SFG-Nes-HSV1sr39tk/GFP vector, resulting in the SFG-NesHSV1-A167Ytk/GFP retroviral vector (HSV1-A167Ytk) and the SFG-Nes-HSV1-A167Ysr39tk/GFP retroviral vector (HSV1A167Ysr39tk), respectively.

\section{Transduction of Tumor Cells}

The U87 human glioma cell line (American Type Culture Collection) was grown as monolayers of cells in modified Eagle medium at $37^{\circ} \mathrm{C}$. The in vitro transduction of U87 cells with the retroviral vectors was accomplished by exposing the cell monolayers to a filtered $(0.45 \mu \mathrm{m})$ culture medium obtained from vectorproducing H29GPG cells (31) for $8 \mathrm{~h}$ in the presence of Polybrene (8 $\mu \mathrm{g} / \mathrm{mL} ;$ Sigma).

\section{Flow Cytometry and Fluorescence Microscopy}

Retrovirus-transduced U87 cells were grown as bulk cultures for $48 \mathrm{~h}$ and subsequently sorted for GFP expression by fluorescenceactivated cell sorting (FACS; FACSVantage; Becton Dickinson); a 488-nm excitation beam and 510-nm emission filters were used. Subcellular localization of the reporter proteins in transduced tumor cells was visualized by fluorescence microscopy (Niko) with similar excitation and emission parameters.

\section{${ }^{3} \mathrm{H}-\mathrm{FEAU},{ }^{3} \mathrm{H}-\mathrm{PCV}$, and ${ }^{3} \mathrm{H}-\mathrm{GCV}$ In Vitro Accumulation Assays}

The ${ }^{3} \mathrm{H}-\mathrm{FEAU},{ }^{3} \mathrm{H}-\mathrm{PCV}$, and ${ }^{3} \mathrm{H}-\mathrm{GCV}$ accumulation assays were performed as previously described ( 6 ). In brief, cells were used to seed tissue culture plates $(150 \times 25 \mathrm{~mm}$; Nunc $)$ at a concentration of $2 \times 10^{6}$ cells per plate and were grown to $50 \%-60 \%$ confluence. The incubation medium contained ${ }^{3} \mathrm{H}-\mathrm{FEAU}$ at $3.7 \mathrm{kBq} / \mathrm{mL}(1.48 \mathrm{TBq} /$ $\mathrm{mmol}),{ }^{3} \mathrm{H}-\mathrm{PCV}$ at $3.7 \mathrm{kBq} / \mathrm{mL}(1.11 \mathrm{TBq} / \mathrm{mmol})$, or ${ }^{3} \mathrm{H}-\mathrm{GCV}$ at 3.7 $\mathrm{kBq} / \mathrm{mL}(1.11 \mathrm{TBq} / \mathrm{mmol}$ ) (purity, >99\%; Moravek Biochemicals). The cells were harvested by scraping after various periods of incubation $(30,60$, and $120 \mathrm{~min}$ ) and centrifuged at $1,250 \mathrm{~g}$; the cell pellets were weighed, reconstituted in solubilization buffer (Soluene-350; PerkinElmer) and scintillation buffer (Insta-Fluor Plus; PerkinElmer), and assayed for radioactivity concentrations by use of a TriCarb $1600 \beta$-spectrometer (Packard) with a standard ${ }^{3} \mathrm{H}$ channel counting technique. The data were expressed as a ratio of the concentration in harvested cells to the concentration in the medium: (dpm/g of cells) $/(\mathrm{dpm} / \mathrm{mL}$ of medium). The rates of accumulation $\left(\mathrm{K}_{\mathrm{i}}\right)$ for ${ }^{3} \mathrm{H}-\mathrm{FEAU},{ }^{3} \mathrm{H}-\mathrm{PCV}$, and ${ }^{3} \mathrm{H}-\mathrm{GCV}$ were determined from slopes of plots of the ratio of the concentration in cells to the concentration in the medium versus incubation times and are expressed as units of tracer clearance from the medium ( $\mathrm{mL}$ of $\mathrm{medium} / \mathrm{min} / \mathrm{g}$ of cells).

\section{Prodrug Sensitivity Assays}

To determine the cytotoxic effects (50\% inhibitory concentrations $\left[\mathrm{IC}_{50} \mathrm{~s}\right]$ ) of $\mathrm{GCV}$, thymine $1-\beta-\mathrm{D}-$ arabinofuranoside (ARA-T; 
A

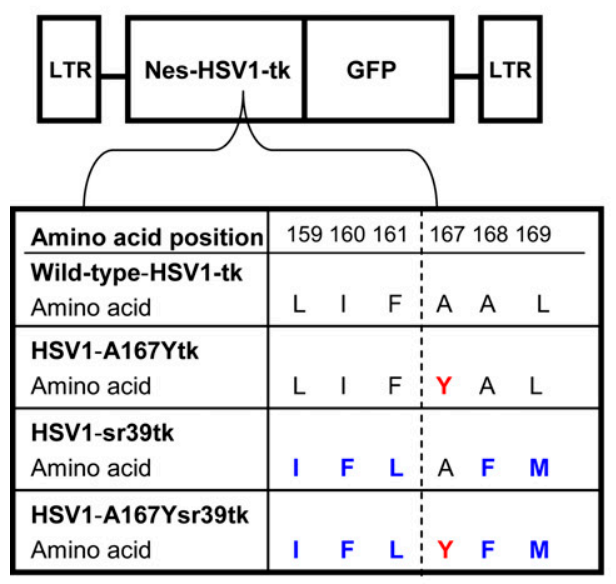

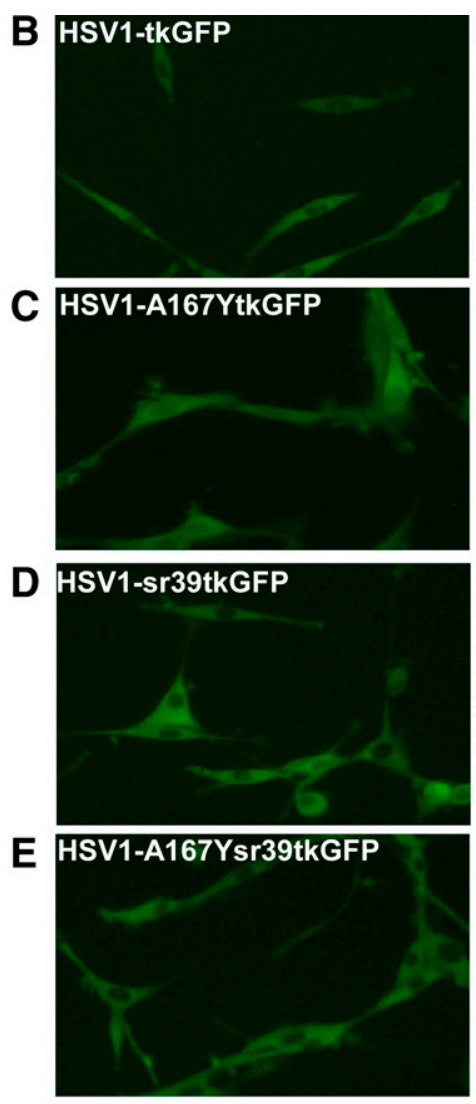

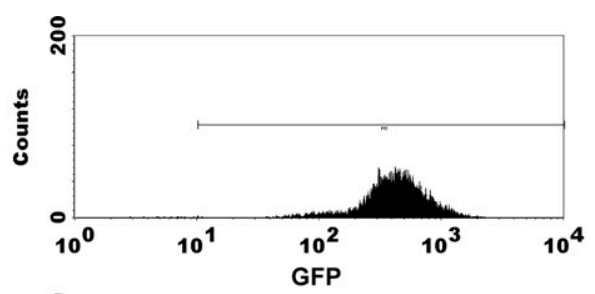
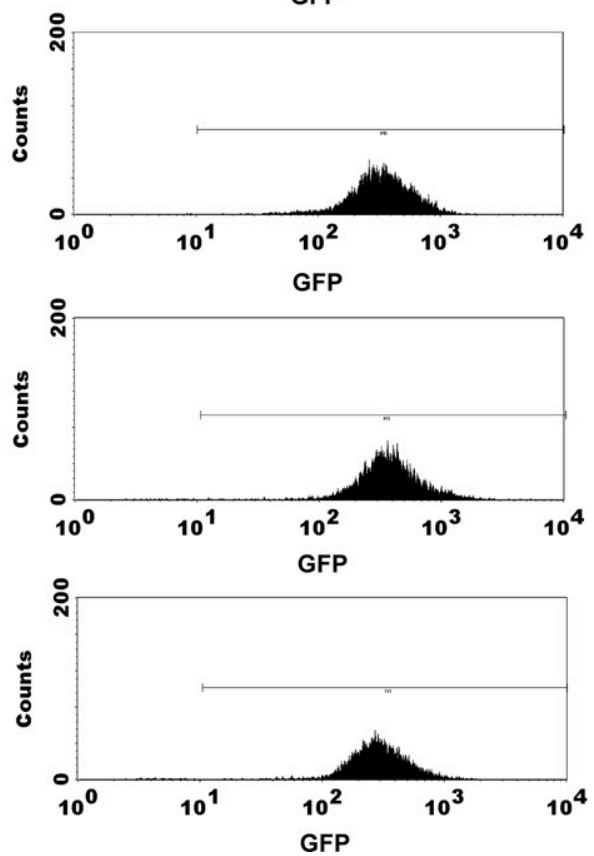

FIGURE 1. Schematic structure of retroviral vectors for mammalian expression. (A) Amino acid differences between wild-type HSV1-tkGFP and different HSV1-tkGFP mutants. (B-E) Fluorescence microscopy and FACS profiles of transduced U87 cells with wild-type HSV1-tkGFP (B), HSV1-A167YtkGFP (C), HSV1-sr39tkGFP (D), and HSV1-A167Ysr39tkGFP (E) reporter genes with GFP filter set. Addition of NES from mitogen-activated protein kinase kinase contributed to cytoplasmic localization of HSV1-tkGFP fusions. LTR = retroviral long terminal repeat.

Sigma), and BVdU (Sigma) on nontransduced and transduced U87 cells, a WST-1 (Roche) cell viability assay was performed $4 \mathrm{~d}$ after exposure to the drugs. Cells were plated on 96-well microtiter plates at an initial density of 4,000 cells per well; GCV, ARA-T, or BVdU was added to sets of 8 wells for each concentration tested. The drug concentrations ranged from $1 \mathrm{nM}$ to $10 \mathrm{mM}$.

\section{Experimental Groups of Animals}

All animal studies were performed under a protocol approved by the Institutional Animal Care and Use Committee of Memorial Sloan-Kettering Cancer Center. Six- to 8-wk-old nude mice (Taconic) were used; $5 \times 10^{6}$ cells per tumor were implanted. Three groups of animals (groups 1,2, and 3; 5 animals per group) were studied, and 3 xenografts were produced in each animal. U87/ nontransduced and U87/HSV1-A167Ysr39tk xenografts were established in the left thigh and the right shoulder, respectively, of each animal in all of the groups. The third xenograft was established in the left shoulder from U87/wild-type HSV1-tk, U87/HSV1-A167Ytk, and U87/HSV1-sr39tk cells in groups 1, 2, and 3, respectively. The mice were anesthetized with a $2 \%: 98 \%$ isoflurane:oxygen gas mixture. All animals were sacrificed by $\mathrm{CO}_{2}$ inhalation.

\section{PET Imaging with ${ }^{18}$ F-FEAU and ${ }^{18}$ F-FHBG}

The animals were monitored daily for tumor growth. Imaging studies were performed when subcutaneous tumors reached $\sim 10$ $\mathrm{mm}$ in diameter. ${ }^{18} \mathrm{~F}$-FEAU $(18)$ and ${ }^{18} \mathrm{~F}$-FHBG were prepared as previously described (32). Small-animal PET imaging was performed $2 \mathrm{~h}$ after tail vein administration of $7.4 \mathrm{MBq}(200 \mu \mathrm{Ci})$ of ${ }^{18} \mathrm{~F}-\mathrm{FEAU}$ (specific activity, $37 \mathrm{TBq} / \mathrm{mmol}$ ) to each animal. After the ${ }^{18} \mathrm{~F}$ radioactivity decayed $(24 \mathrm{~h}$ later), the same animals were injected via the tail vein with $7.4 \mathrm{MBq}(200 \mu \mathrm{Ci})$ of ${ }^{18} \mathrm{~F}-\mathrm{FHBG}$ (specific activity, $44.4 \mathrm{TBq} / \mathrm{mmol}$ ) and imaged $2 \mathrm{~h}$ later. PET was performed with a FOCUS 120 microPET scanner (Siemens Preclinical Solutions). At least $10^{7}$ coincidence events were acquired per study with a 350- to 750-keV energy window and a 6-ns timing window. List-mode data were sorted into sinograms by Fourier rebinning and reconstructed by filtered backprojection without attenuation or scatter correction. Count data in the reconstructed images were converted to activity concentrations (i.e., percentage injected dose $/ \mathrm{cm}^{3}\left[\% \mathrm{ID} / \mathrm{cm}^{3}\right]$ ) on the basis of a system calibration factor determined from an ${ }^{18} \mathrm{~F}$-filled mouse-size phantom. Visualization and analyses of small-animal PET images were performed with AsiPRO software (Siemens Preclinical Solutions). Radioactivity concentrations in tissues were calculated by use of the maximum pixel values from small-animal PET images.

\section{Tissue Sampling and Radioactivity Measurements}

Immediately after the ${ }^{18} \mathrm{~F}-\mathrm{FHBG}$ imaging sessions, animals were sacrificed. Tumors and muscle tissue were excised, washed, and weighed. Radioactivity concentrations in tissue samples were 
measured for 1 min with a $\gamma$-counter (model A5550; Packard), normalized to sample weight, and expressed as the percentage injected dose per gram of tissue $(\% \mathrm{ID} / \mathrm{g})$, transduced-to-nontransduced tumor accumulation ratios, and tissue-to-muscle accumulation ratios.

\section{Statistical Analysis}

All cell culture and mouse group comparisons were performed with a Student $t$ test for independent samples with unequal variances. Mean values and independent $t$ tests for unequal variances were calculated with Graph Prism 4 software (GraphPad Software). $P$ values of $<0.05$ were considered statistically significant.

\section{RESULTS}

\section{Characterization of Reporter Genes In Vitro}

The subcellular localization of reporter gene products was accessed in transduced U87 cells by fluorescence microscopy. Fluorescence microscopy analysis demonstrated cytoplasmic distribution of wild-type HSV1-tkGFP, HSV1-A167YtkGFP, HSV1-sr39tkGFP, and HSV1A167Ysr39tkGFP reporter proteins attributable to the presence of the NES signal at the $\mathrm{N}$ terminus (Figs. 1B-1E). Transduced cells were sorted for GFP-positive populations with similar levels of GFP expression ( $~ 500$ fluorescence units). After FACS, all cell lines were found to be greater than 95\% GFP positive.

The levels of enzymatic activities of wild-type HSV1-tk, HSV1-A167Ytk, HSV1-sr39tk, and HSV-A167Ysr39tk proteins were assessed by use of a previously established radiotracer accumulation assay with ${ }^{3} \mathrm{H}-\mathrm{FEAU},{ }^{3} \mathrm{H}-\mathrm{PCV}$, and ${ }^{3} \mathrm{H}-\mathrm{GCV}$ (Fig. 2). In nontransduced U87 cells, background levels of ${ }^{3} \mathrm{H}-\mathrm{FEAU},{ }^{3} \mathrm{H}-\mathrm{PCV}$, and ${ }^{3} \mathrm{H}-\mathrm{GCV}$ uptake were detected. ${ }^{3} \mathrm{H}-\mathrm{FEAU}$ was efficiently accumulated by wild-type HSV1-tk-positive and HSV1-sr39tk-positive cells $\left(\mathrm{K}_{\mathrm{i}} \mathrm{s}\right.$ of 0.47 and $0.69 \mathrm{~mL} / \mathrm{min} / \mathrm{g}$ of cells; $\left.P<0.05\right)$. In contrast, no ${ }^{3} \mathrm{H}-\mathrm{FEAU}$ accumulation was observed in HSV1A167Ytk-positive and HSV1-A167Ysr39tk-positive cells. All transduced cell lines showed positive ${ }^{3} \mathrm{H}-\mathrm{PCV}$ uptake compared with nontransduced U87 cells. U87/wild-type

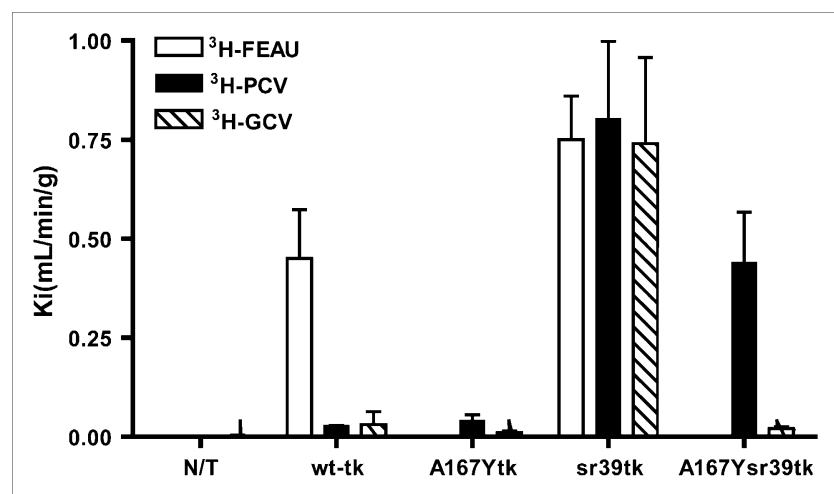

FIGURE 2. Radiotracer uptake $\left(\mathrm{K}_{\mathrm{i}}\right)$ of ${ }^{3} \mathrm{H}-\mathrm{FEAU},{ }^{3} \mathrm{H}-\mathrm{PCV}$, and ${ }^{3} \mathrm{H}-\mathrm{GCV}$ in nontransduced $(\mathrm{N} / \mathrm{T})$ and transduced U87 cells shown on abscissa. Values are mean \pm SD. Data represent at least 3 independent experiments.
HSV1-tk and U87/HSV1-A167Ytk cells showed almost similar levels of ${ }^{3} \mathrm{H}-\mathrm{PCV}$ uptake $\left(\mathrm{K}_{\mathrm{i}} \mathrm{s}\right.$ of 0.028 and $0.04 \mathrm{~mL} / \mathrm{min} / \mathrm{g}$ of cells, respectively). Cells expressing the HSV1-A167Ysr39tk mutant showed higher levels of ${ }^{3} \mathrm{H}-\mathrm{PCV}$ accumulation $\left(\mathrm{K}_{\mathrm{i}}\right.$ of $0.44 \mathrm{~mL} / \mathrm{min} / \mathrm{g}$ of cells; $P<0.05$ ) than wild-type HSV1-tk and HSV1-A167Ytk cells. The highest level of accumulation of ${ }^{3} \mathrm{H}-\mathrm{PCV}$ was observed in HSV1-sr39tk-positive cells $\left(\mathrm{K}_{\mathrm{i}}\right.$ of $0.8 \mathrm{~mL} / \mathrm{min} / \mathrm{g}$ of cells). All transduced cells showed positive ${ }^{3} \mathrm{H}-\mathrm{GCV}$ uptake compared with nontransduced U87 cells; however, only U87/HSV1-sr39tk cells demonstrated a significantly higher level of accumulation of ${ }^{3} \mathrm{H}-\mathrm{GCV}$ among transduced cells.

To explore the possibility of killing of transduced cells with a prodrug activation suicide therapy approach, wildtype and transduced U87 cells were tested for in vitro sensitivity to the clinically relevant nucleoside analogs GCV, ARA-T, and BVdU (Fig. 3). HSV1-sr39tk-positive cells showed the lowest $\mathrm{IC}_{50}$ for $\mathrm{GCV}(0.12 \mu \mathrm{M})$. Wild-type HSV1-tk-expressing, HSV1-A167Ytk-expressing, and HSV1A167Ysr39tk-expressing cells showed comparable sensitivities to $\mathrm{GCV}$ ( $\mathrm{IC}_{50} \mathrm{~s}$ of 11,50 , and $6.0 \mu \mathrm{M}$, respectively). The $\mathrm{IC}_{50}$ for nontransduced cells with $\mathrm{GCV}$ was greater than $1 \mathrm{mM}$. Only wild-type HSV1-tk-positive and HSV1-sr39tkpositive cells were sensitive to $\mathrm{BVdU}\left(\mathrm{IC}_{50} \mathrm{~S}\right.$ of 1.3 and 2.1 $\mu \mathrm{M}$, respectively) and ARA-T $\left(\mathrm{IC}_{50}\right.$ s of 140 and $180 \mu \mathrm{M}$, respectively); HSV1-A167Ytk-positive, HSV1-A167Ysr39tkpositive, and nontransduced cells were not $\left(\mathrm{IC}_{50} \mathrm{~s}\right.$ of $>10 \mathrm{mM}$ ).

\section{In Vivo Imaging of Reporter Gene Expression with PET}

Small-animal PET imaging studies were performed in mice bearing subcutaneous xenografts derived from transduced U87 cell populations and wild-type U87 cells, which served as a negative control (Fig. 4). The levels of ${ }^{18} \mathrm{~F}$ FEAU and ${ }^{18} \mathrm{~F}-\mathrm{FHBG}$ radioactivity in control (nontransduced) U87 tumors were very low and similar to the body background. Small-animal PET imaging revealed a highly specific localization of ${ }^{18} \mathrm{~F}$-FEAU-derived radioactivity in xenografts expressing the wild-type HSV1-tk and HSV1sr39tk reporter genes, with a marginal advantage favoring the HSV1-sr39tk mutant $(P<0.05)$ (Fig. 4). No ${ }^{18}$ F-FEAU accumulation was observed in HSV1-A167Ytk-expressing and HSV1-A167Ysr39tk-expressing tumors. ${ }^{18} \mathrm{~F}-\mathrm{FHBG}$ uptake was observed in all transduced tumors. U87/wild-type HSV1-tk and U87/HSV1-A167Ytk tumors showed similar levels of ${ }^{18} \mathrm{~F}$-FHBG uptake. A 2.5 -fold-higher level of ${ }^{18} \mathrm{~F}$ FHBG accumulation was observed in HSV1-A167Ysr39tkexpressing tumors than in U87/wild-type HSV1-tk and U87/ HSV1-A167Y tumors $(P<0.05)$. The highest level of accumulation of ${ }^{18} \mathrm{~F}-\mathrm{FHBG}$ was observed in U87/HSV1sr39tk tumors (6-fold higher than in U87/wild-type HSV1-tk tumors; $P<0.05)$. Tissue sampling and biodistribution studies confirmed ${ }^{18} \mathrm{~F}-\mathrm{FEAU}$ and ${ }^{18} \mathrm{~F}-\mathrm{FHBG}$ accumulation in U87/ wild-type HSV1-tk and U87/HSV1-sr39tk tumors and highly specific ${ }^{18} \mathrm{~F}-\mathrm{FHBG}$-derived radioactivity in U87/HSV1A167Ytk and U87/HSV1-A167Ysr39tk tumors (Fig. 5). Non- 


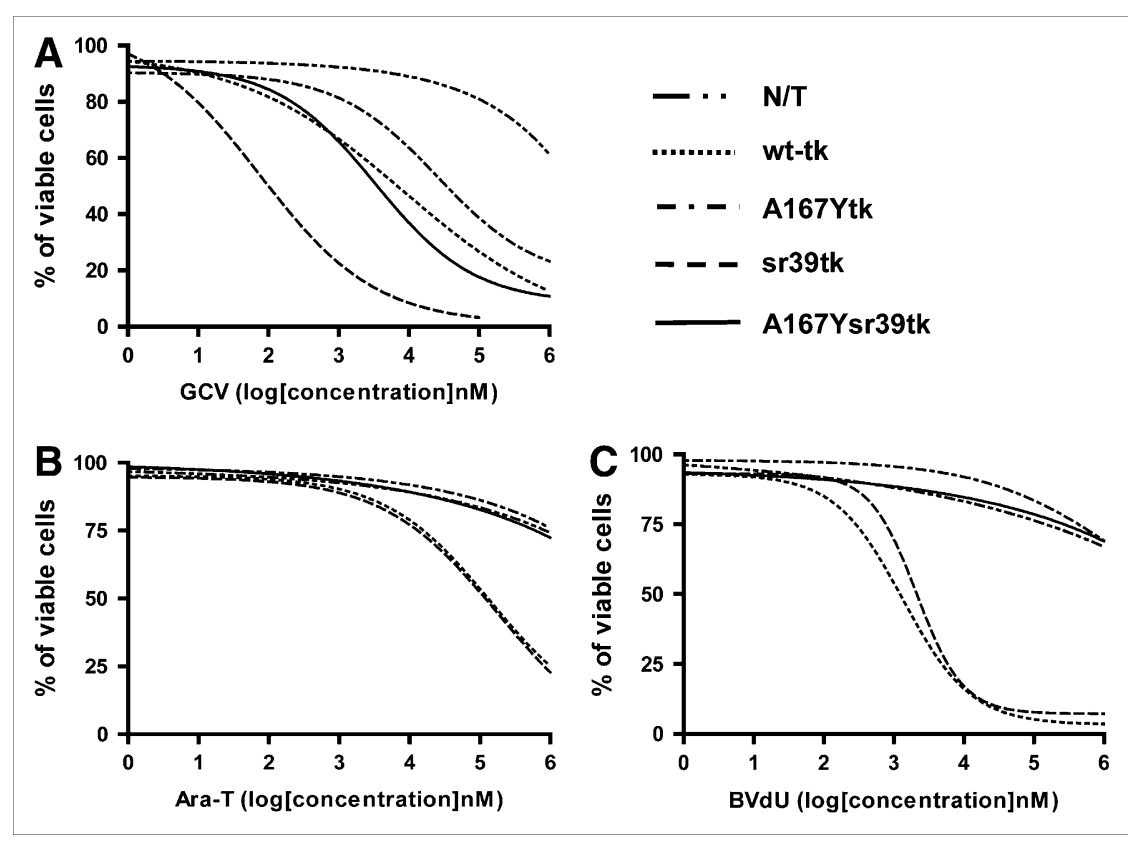

FIGURE 3. Assessment of drug sensitivity of nontransduced (N/T) and transduced U87 cells to nucleoside analogs GCV (A), ARA-T (B), and BVdU (C) in vitro. $1 \mathrm{C}_{50} \mathrm{~S}$ are given in text. Data represent 3 independent experiments. transduced U87 tumors and muscle tissue showed only low background levels of radioactivity. Transduced-to-nontransduced xenograft ratios and transduced xenograft-to-muscle ratios for ${ }^{18} \mathrm{~F}-\mathrm{FHBG}$ were calculated and are shown in Table 1.

\section{DISCUSSION}

HSV1-tk is widely used in gene therapy studies as a suicide gene in combination with GCV and as a nuclear imaging reporter gene in combination with an appropriate reporter probe. Radiolabeled pyrimidine-based ( ${ }^{124} \mathrm{I}-\mathrm{FEAU}$, ${ }^{18}$ F-FIAU, ${ }^{18}$ F-FEAU, ${ }^{18}$ F-FFEAU, and ${ }^{18}$ F-FMAU) $(15,17,19-$ $21)$ and acycloguanosine-based $\left({ }^{18} \mathrm{~F}-\mathrm{GCV},{ }^{18} \mathrm{~F}-\mathrm{FHBG}\right.$, and ${ }^{18}$ F-FHPG) $(22,33-35)$ nucleoside analogs have been used to image HSV1-tk and HSV1-sr39tk reporter gene expression with PET. HSV1-tk can also phosphorylate a variety of cytotoxic pyrimidine and acycloguanosine derivatives, including clinically used antiviral drugs such as GCV, ACV, and BVdU (25-27). In a clinical setting in which a patient's condition requires the administration of antiviral drugs, cells expressing HSV1-tk as a reporter gene will be compromised by antiviral treatment. This will result in the negative selection of HSV1-tk-transduced cells and inaccurate imaging results with HSV1-tk-specific PET tracers. The objective of this work was to create a new acycloguanosine-specific mutant of the HSV1-tk reporter gene family that will allow for successful PET in patients undergoing therapy with pyrimidine-based nucleoside analogs. For example, noninvasive PET of acycloguanosine-specific HSV1-tk mutant expression with acycloguanosine-based radiotracers (e.g., ${ }^{18} \mathrm{~F}-\mathrm{FHBG}$ ) will not be compromised by treatment with $\mathrm{BVdU}$ or other pyrimidinebased nucleoside analogs.

Recently, Degreve et al. showed that position 167 in the HSV1-tk protein is particularly favorable for discriminating between pyrimidine and acycloguanosine substrates $(28,29)$.
In their studies, a mutant bearing the A167Y substitution in the nucleoside-binding region (amino acids 159-169) (Fig. 1A) showed a markedly decreased response to the antiviral pyrimidines (ARA-T and BVdU in particular), whereas the phosphorylation of GCV, ACV, and PCV was almost not affected by this mutation. These results were confirmed in our in vitro and in vivo studies (Figs. 2-5). Moreover, we showed for the first time that cells transduced with the HSV1-A167Ytk mutant were not able to accumulate FEAU in vitro and in vivo, whereas the uptake of ${ }^{3} \mathrm{H}-\mathrm{GCV}$ and ${ }^{3} \mathrm{H}-\mathrm{PCV}$ in vitro and the uptake of ${ }^{18} \mathrm{~F}-\mathrm{FHBG}$ in vivo were found to be similar to those in cells transduced with wildtype HSV1-tk.

Several groups have performed genetic modifications of the wild-type HSV1-tk which resulted in mutants with enhanced phosphorylation kinetics for certain nucleoside derivatives. The widely used HSV1-sr39tk mutant, bearing 5 amino acid substitutions in the nucleoside-binding region of the enzyme (Fig. 1) (36,37), shows significantly improved activity with acycloguanosines, specifically GCV, ACV, and PCV. This mutant demonstrated a greater-than100 -fold reduction in the $\mathrm{IC}_{50}$ for $\mathrm{GCV}$ compared with wild-type HSV1-tk-expressing transfectants. When used in vivo for PET studies, HSV1-sr39tk-expressing tumors showed considerably increased uptake of the PCV analog ${ }^{18}$ F-FHBG $(22,38)$ compared with wild-type HSV1-tktransduced xenografts. We confirmed these results in the present study. The $\mathrm{IC}_{50}$ for GCV with HSV1-sr39tk-transduced cells was 2 orders of magnitude lower than that with wild-type HSV1-tk-expressing transfectants (Fig. 3), and ${ }^{18}$ F-FHBG accumulation was found to be $\sim 6$-fold higher in HSV1-sr39tk-expressing tumors than in wild-type HSV1tk-expressing xenografts (Figs. 4 and 5). Also, in accordance with in vitro studies by Kang et al. (39), we found 


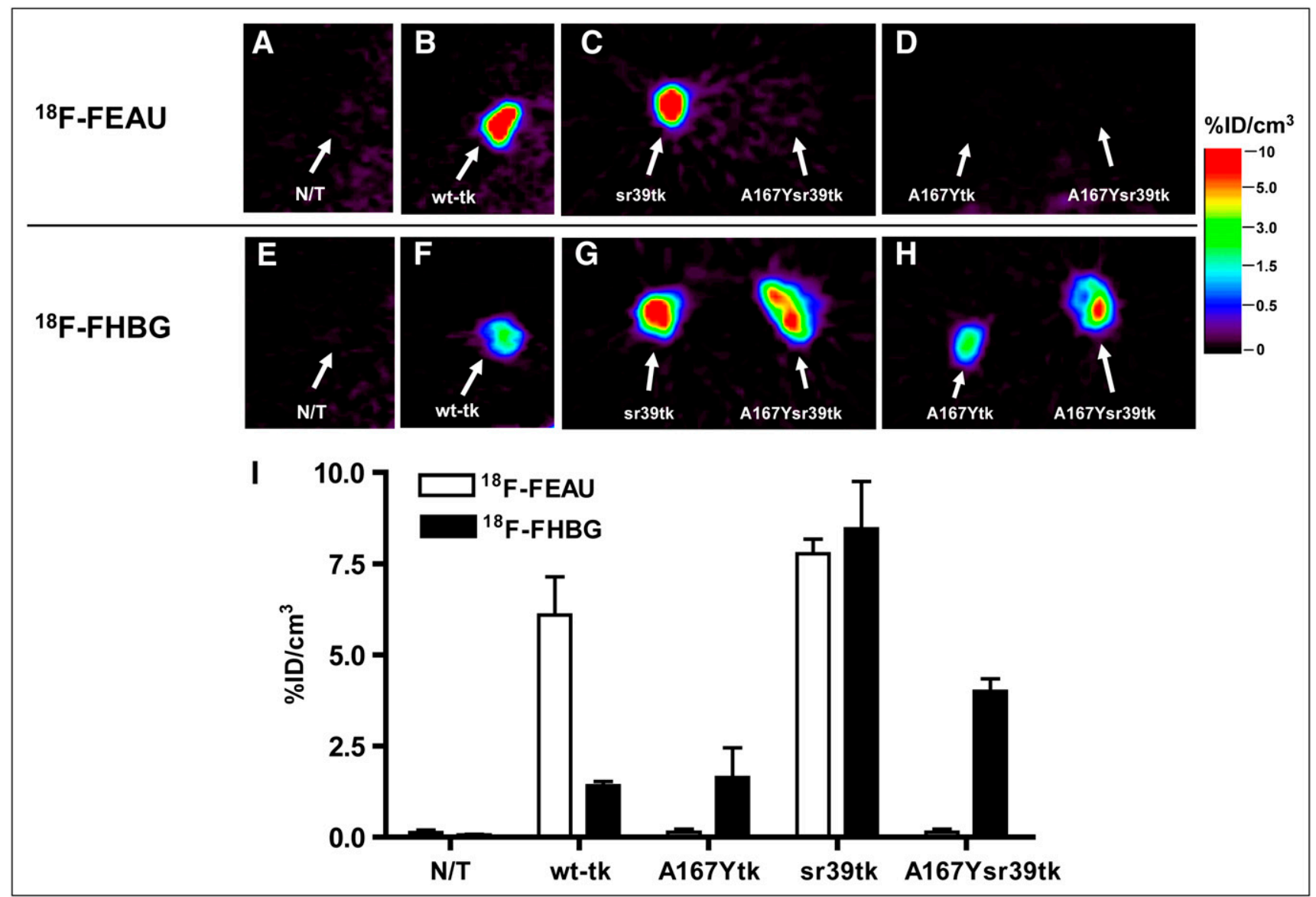

FIGURE 4. Small-animal PET imaging of reporter gene expression. (A-H) Small-animal PET imaging of nontransduced (N/T) U87 xenografts (A and $E$ ) and transduced U87 xenografts, including wild-type HSV1-tk (B and F), HSV1-sr39tk (C and G), HSV1A167Ytk (D and H), and HSV1-A167Ysr39tk (C, D, G, and H), with ${ }^{18} \mathrm{~F}-\mathrm{FEAU}$ (upper row) and ${ }^{18} \mathrm{~F}-\mathrm{FHBG}$ (lower row) at $2 \mathrm{~h}$ after radiotracer administration. (I) Image-based measurements of ${ }^{18} \mathrm{~F}-\mathrm{FEAU}$ and ${ }^{18} \mathrm{~F}-\mathrm{FHBG}$ at $2 \mathrm{~h}$ after radiotracer administration, expressed as \%ID/cm ${ }^{3}$ of tissue $(n=5, P<0.05)$. Values are mean \pm SD.

that the level of ${ }^{18} \mathrm{~F}-\mathrm{FEAU}$ phosphorylation obtained in vivo with this mutant is slightly superior to that obtained with wild-type HSV1-tk $(P<0.05)$. These results led us to conclude that the HSV1-sr39tk mutant exhibits a more favorable conformation of the nucleoside-binding pocket

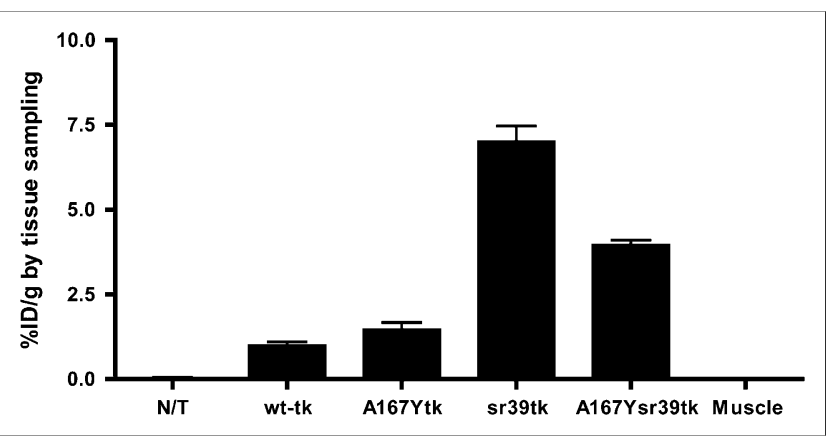

FIGURE 5. Tissue sampling-based measurements of ${ }^{18} \mathrm{~F}$ FHBG accumulation at $2 \mathrm{~h}$ after radiotracer administration, expressed as \%ID/g $(n=5, P<0.05)$. Values are mean \pm SD. $\mathrm{N} / \mathrm{T}=$ nontransduced U87 tumors. for both pyrimidine and acycloguanosine derivatives with a marginal increase in the rate of phosphorylation for the latter compared with the wild-type enzyme.

HSV1-sr39tk contains an alanine residue at position 167, similar to the wild-type protein (37). On the basis of this observation, we hypothesized that the substitution of the alanine at position 167 with a pyrimidine-restrictive tyrosine within this mutant may lead to newly acquired specificity and high phosphorylation activity with acycloguanosine analogs without interference from pyrimidine-based derivatives. We were able to successfully develop and express in U87 cells a new supermutant of HSV1-tk, HSV1-A167Ysr39tk fused with GFP, at levels comparable to those of wild-type HSV1-tk and other mutants. In our experiments, FEAU accumulation in HSV1-A167Ysr39tk-transduced cells could not be detected in vitro (Fig. 2) or in vivo (Fig. 4). Lack of pyrimidine phosphorylation by the HSV1-A167Ysr39tk supermutant was also confirmed with drug sensitivity assays, in which the $\mathrm{IC}_{50} \mathrm{~s}$ for ARA-T and BVdU were similar to those in nontransduced cells (Figs. 3B and 3C). In contrast, we found that HSV1-A167Ysr39tk could readily phosphor- 
TABLE 1

Calculated Transduced-to-Nontransduced Tumor and Tissue-to-Muscle Radiotracer Accumulation Ratios for ${ }^{18}$ F-FHBG In Vivo $(n=5, P<0.05)$

\begin{tabular}{lrrrrrr}
\hline & \multicolumn{5}{c}{$\% \mathrm{ID} / \mathrm{g}(\mathrm{mean} \pm \mathrm{SD})$ for the following sample: } \\
\cline { 2 - 7 } \multicolumn{1}{c}{ Ratio } & \multicolumn{1}{c}{ wt-tk } & A167Ytk & sr39tk & A167Ysr39tk & Nontransduced tumor & Muscle \\
\hline Transduced-to-nontransduced tumor & $22.4 \pm 1.3$ & $30 \pm 12$ & $146 \pm 19$ & $82 \pm 12$ & 1 & \\
Tissue-to-muscle & $31 \pm 2.7$ & $42 \pm 11$ & $204 \pm 17$ & $115 \pm 16$ & $1.4 \pm 0.1$ & 1 \\
\hline
\end{tabular}

ylate GCV at a level similar to that of wild-type HSV1-tk (or HSV1-A167Ytk) (Fig. 2) but showed enhanced activity with PCV in vitro ( $\sim 10$ - to 15 -fold) (Fig. 2$)$ and ${ }^{18}$ F-FHBG in vivo ( $\sim 2.5$-fold) (Figs. 4 and 5). Interestingly, despite a substantial increase in ${ }^{3} \mathrm{H}-\mathrm{PCV}$ and ${ }^{18} \mathrm{~F}-\mathrm{FHBG}$ uptake observed with HSV1-A167Ysr39tk relative to that observed with wild-type HSV1-tk or HSV1-A167Ytk, the $\mathrm{IC}_{50}$ s for GCV were comparable among wild-type HSV1-tk and both A167Y-containing mutants (Fig. 3A). Thus, the A167Y substitution within the HSV1-sr39tk mutant led to a particular analog-specific enhancement of uptake within the acycloguanosine group.

The in vivo imaging results demonstrated the advantage of the new acycloguanosine-specific supermutant HSV1A167Ysr39tk reporter gene over its predecessor, HSV1A167Ytk. Both PET and direct measurement of radiotracer accumulation in tissue samples confirmed a much higher level of ${ }^{18} \mathrm{~F}-\mathrm{FHBG}$ uptake in HSV1-A167Ysr39tk-expressing tumors than in HSV1-A167Ytk-expressing xenografts. On the basis of our in vitro and in vivo data, we are more than confident that our supermutant can be reliably imaged with PET and ${ }^{18} \mathrm{~F}$-FHBG in patients treated with pyrimidine derivatives while providing an opportunity to eliminate transduced cells with GCV administration.

${ }^{18} \mathrm{~F}-\mathrm{FHBG}$ is known to be cleared via the liver and kidneys, a property that makes it more challenging to elucidate HSV1-tk reporter gene expression in the lower gut. Therefore, the same issue of gastrointestinal clearance of ${ }^{18} \mathrm{~F}-\mathrm{FHBG}$ remains to be addressed.

The alternative strategy of using a pyrimidine-specific mutant of the HSV1-tk reporter gene will be useful and will allow PET in patients undergoing therapy with acycloguanosine-based analogs. Studies on the development of such a mutant are under way.

\section{CONCLUSION}

We successfully developed and tested a new supermutant of the HSV1-tk reporter gene, HSV1-A167Ysr39tk, in vitro and in vivo. This reporter gene lacks the ability to convert pyrimidine-based nucleoside derivatives but exhibits high phosphorylation activity with acycloguanosine analogs. This supermutant potentially can be used as a suicide gene for prodrug (GCV) activation in vivo and as an acycloguanosine-specific PET reporter gene for imaging with ${ }^{18} \mathrm{~F}-$
FHBG in patients treated with pyrimidine-based cytotoxic drugs.

\section{ACKNOWLEDGMENTS}

We thank Dr. Ronald Blasberg for his invaluable help in the preparation of the article. We thank Dr. Ronald Finn, Dr. Pat Zanzonico, and Dr. Maxim Moroz for their expert technical assistance. We specifically thank Dr. Juri Gelovani for his long-term support. This work was financially supported by NIH grants P50 CA86438-01 and R01 CA102352. Technical services were provided by the MSKCC SmallAnimal Imaging Core Facility, supported in part by NIH Small-Animal Imaging Research Program (SAIRP) grant R24 CA83084 and NIH Center grant P30 CA08748.

\section{REFERENCES}

1. Min JJ, Gambhir SS. Gene therapy progress and prospects: noninvasive imaging of gene therapy in living subjects. Gene Ther. 2004;11:115-125.

2. Deng WP, Wu CC, Lee CC, et al. Serial in vivo imaging of the lung metastases model and gene therapy using HSV1-tk and ganciclovir. J Nucl Med. 2006;47: 877-884.

3. Luker GD, Leib DA. Luciferase real-time bioluminescence imaging for the study of viral pathogenesis. Methods Mol Biol (Clifton, NJ). 2005;292:285-296.

4. Dubey PSH, Adonai N, Du S, et al. Quantitative imaging of the T cell antitumor response by positron-emission tomography. Proc Natl Acad Sci USA. 2003;100: $1232-1237$.

5. Koehne G, Doubrovin M, Doubrovina E, et al. Serial in vivo imaging of the targeted migration of human HSV-TK-transduced antigen-specific lymphocytes. Nat Biotechnol. 2003;21:405-413.

6. Tjuvajev JG, Stockhammer G, Desai R, et al. Imaging the expression of transfected genes in vivo. Cancer Res. 1995;55:6126-6132.

7. Haberkorn U, Altmann A, Morr I, et al. Monitoring gene therapy with herpes simplex virus thymidine kinase in hepatoma cells: uptake of specific substrates. J Nucl Med. 1997;38:287-294.

8. Ponomarev V, Doubrovin M, Shavrin A, et al. A human-derived reporter gene for noninvasive imaging in humans: mitochondrial thymidine kinase type 2 . J Nucl Med. 2007;48:819-826.

9. Che J, Doubrovin M, Serganova I, Ageyeva L, Zanzonico P, Blasberg R. hNISIRES-eGFP dual reporter gene imaging. Mol Imaging. 2005;4:128-136.

10. Moroz MA, Serganova I, Zanzonico P, et al. Imaging hNET reporter gene expression with ${ }^{124}$ I-MIBG. $J$ Nucl Med. 2007;48:827-836.

11. Genove G, DeMarco U, Xu H, Goins WF, Ahrens ET. A new transgene reporter for in vivo magnetic resonance imaging. Nat Med. 2005;11:450-454.

12. Moore A, Josephson L, Bhorade RM, Basilion JP, Weissleder R. Human transferrin receptor gene as a marker gene for MR imaging. Radiology. 2001;221: 244-250.

13. Bonini C, Ferrari G, Verzeletti S, et al. HSV-TK gene transfer into donor lymphocytes for control of allogeneic graft-versus-leukemia. Science (New York, NY). 1997;276:1719-1724.

14. Choi SR, Zhuang ZP, Chacko AM, et al. SPECT imaging of herpes simplex virus type1 thymidine kinase gene expression by $\left[{ }^{123} \mathrm{I}\right] \mathrm{FIAU(1).} \mathrm{Acad} \mathrm{Radiol.}$ 2005;12:798-805. 
15. Tjuvajev JG, Avril N, Oku T, et al. Imaging herpes virus thymidine kinase gene transfer and expression by positron emission tomography. Cancer Res. 1998;58: 4333-4341.

16. Zinn KR, Chaudhuri TR, Krasnykh VN, et al. Gamma camera dual imaging with a somatostatin receptor and thymidine kinase after gene transfer with a bicistronic adenovirus in mice. Radiology. 2002;223:417-425.

17. Alauddin MM, Shahinian A, Park R, Tohme M, Fissekis JD, Conti PS. In vivo evaluation of $2^{\prime}$-deoxy-2'-[ $\left.{ }^{18} \mathrm{~F}\right]$ fluoro-5-iodo-1- $\beta$-D-arabinofuranosyluracil $\left(\left[{ }^{18} \mathrm{~F}\right] \mathrm{FIAU}\right)$ and $2^{\prime}$-deoxy-2' $-\left[{ }^{18} \mathrm{~F}\right]$ fluoro-5-ethyl-1- $\beta$-D-arabinofuranosyluracil $\left(\left[{ }^{18} \mathrm{~F}\right] \mathrm{FEAU}\right)$ as markers for suicide gene expression. Eur $\mathrm{J} \mathrm{Nucl}$ Med Mol Imaging. 2007;34:822-829.

18. Alauddin MMFJ, Conti PS. Synthesis of $\left[{ }^{18} \mathrm{~F}\right]$-labeled $2^{\prime}$-deoxy-2'-fluoro-5methyl-1- $\beta$-D-arabinofuranosyluracil ([$\left.{ }^{18} \mathrm{~F}\right]$-FMAU). J Labelled Comp Radiopharm. 2002;45:583-590.

19. Serganova I, Doubrovin M, Vider J, et al. Molecular imaging of temporal dynamics and spatial heterogeneity of hypoxia-inducible factor-1 signal transduction activity in tumors in living mice. Cancer Res. 2004;64:6101-6108.

20. Alauddin MM, Shahinian A, Gordon EM, Conti PS. Evaluation of $2^{\prime}$-deoxy-2'fluoro-5-methyl-1- $\beta$-D-arabinofuranosyluracil as a potential gene imaging agent for HSV-tk expression in vivo. Mol Imaging. 2002;1:74-81.

21. Balatoni JA, Doubrovin M, Ageyeva L, et al. Imaging herpes viral thymidine kinase-1 reporter gene expression with a new ${ }^{18} \mathrm{~F}$-labeled probe: $2^{\prime}$-fluoro-2'deoxy-5-[ ${ }^{18}$ F]fluoroethyl-1- $\beta$-d-arabinofuranosyl uracil. Nucl Med Biol. 2005; 32:811-819.

22. Yaghoubi S, Barrio JR, Dahlbom M, et al. Human pharmacokinetic and dosimetry studies of $\left[{ }^{18} \mathrm{~F}\right] \mathrm{FHBG}$ : a reporter probe for imaging herpes simplex virus type-1 thymidine kinase reporter gene expression. J Nucl Med. 2001;42: 1225-1234.

23. Jacobs A, Braunlich I, Graf R, et al. Quantitative kinetics of $\left[{ }^{124} I\right] F I A U$ in cat and man. J Nucl Med. 2001;42:467-475.

24. Peñuelas I, Mazzolini G, Boan JF, et al. Positron emission tomography imaging of adenoviral-mediated transgene expression in liver cancer patients. Gastroenterology. 2005;128:1787-1795.

25. Mwintshi K, Brennan DC. Prevention and management of cytomegalovirus infection in solid-organ transplantation. Expert Rev Anti Infect Ther. 2007;5:295-304.

26. Moomaw MD, Cornea P, Rathbun RC, Wendel KA. Review of antiviral therapy for herpes labialis, genital herpes and herpes zoster. Expert Rev Anti Infect Ther. 2003;1:283-295.

27. De Clercq E. Discovery and development of BVDU (brivudin) as a therapeutic for the treatment of herpes zoster. Biochem Pharmacol. 2004;68:2301-2315.
28. Degreve B, Esnouf R, De Clercq E, Balzarini J. Selective abolishment of pyrimidine nucleoside kinase activity of herpes simplex virus type 1 thymidine kinase by mutation of alanine-167 to tyrosine. Mol Pharmacol. 2000;58:1326-1332.

29. Balzarini J, Liekens S, Esnouf R, De Clercq E. The A167Y mutation converts the herpes simplex virus type 1 thymidine kinase into a guanosine analogue kinase. Biochemistry. 2002;41:6517-6524.

30. Ponomarev V, Doubrovin M, Serganova I, et al. Cytoplasmically retargeted HSV1-tk/GFP reporter gene mutants for optimization of non-invasive moleculargenetic imaging. Neoplasia. 2003;5:245-254.

31. Riviere ISM. Methods for the construction of retroviral vectors and the generation of high titer producers. In: Robbins PD, ed. Gene Therapy Protocols. Totowa, NJ: Humana Press; 1997:59-78.

32. Alauddin MM, Conti PS. Synthesis and preliminary evaluation of 9-(4-[ $\left.{ }^{18} \mathrm{~F}\right]-$ fluoro-3-hydroxymethylbutyl)guanine $\left(\left[{ }^{18} \mathrm{~F}\right] \mathrm{FHBG}\right)$ : a new potential imaging agent for viral infection and gene therapy using PET. Nucl Med Biol. 1998;25: $175-180$.

33. Gambhir SS, Barrio JR, Wu L, et al. Imaging of adenoviral-directed herpes simplex virus type 1 thymidine kinase reporter gene expression in mice with radiolabeled ganciclovir. J Nucl Med. 1998;39:2003-2011.

34. Yaghoubi SS, Gambhir SS. PET imaging of herpes simplex virus type 1 thymidine kinase (HSV1-tk) or mutant HSV1-sr39tk reporter gene expression in mice and humans using $\left[{ }^{18}\right.$ F]FHBG. Nat Protocols. 2006;1:3069-3075.

35. Alauddin MM, Shahinian A, Kundu RK, Gordon EM, Conti PS. Evaluation of 9-[(3- ${ }^{18}$ F-fluoro-1-hydroxy-2-propoxy)methyl]guanine ([ $\left.\left.{ }^{18} \mathrm{~F}\right]-\mathrm{FHPG}\right)$ in vitro and in vivo as a probe for PET imaging of gene incorporation and expression in tumors. Nucl Med Biol. 1999;26:371-376.

36. Gambhir SS, Bauer E, Black ME, et al. A mutant herpes simplex virus type 1 thymidine kinase reporter gene shows improved sensitivity for imaging reporter gene expression with positron emission tomography. Proc Natl Acad Sci USA. 2000;97:2785-2790.

37. Black ME, Kokoris MS, Sabo P. Herpes simplex virus-1 thymidine kinase mutants created by semi-random sequence mutagenesis improve prodrugmediated tumor cell killing. Cancer Res. 2001;61:3022-3026.

38. Yaghoubi SS, Couto MA, Chen CC, et al. Preclinical safety evaluation of ${ }^{18} \mathrm{~F}-\mathrm{FHBG}$ : a PET reporter probe for imaging herpes simplex virus type 1 thymidine kinase (HSV1-tk) or mutant HSV1-sr39tk's expression. J Nucl Med. 2006;47:706-715.

39. Kang KW, Min JJ, Chen X, Gambhir SS. Comparison of $\left[{ }^{14} \mathrm{C}\right] \mathrm{FMAU}$, $\left[{ }^{3} \mathrm{H}\right] \mathrm{FEAU},\left[{ }^{14} \mathrm{C}\right] \mathrm{FIAU}$, and $\left[{ }^{3} \mathrm{H}\right] \mathrm{PCV}$ for monitoring reporter gene expression of wild type and mutant herpes simplex virus type 1 thymidine kinase in cell culture. Mol Imaging Biol. 2005;7:296-303. 